\title{
Attempted Autophagy in a Checkered Keelback, Fowlea piscator (Schneider 1799) (Natricidae) from India
}

\author{
Rahul V. Deshmukh ${ }^{1}$, Sagar A. Deshmukh², Swapnil A. Badhekar ${ }^{3}$, and Sanjay Wasake ${ }^{4}$ \\ ${ }^{1}$ Ward No. 4, Teacher Colony, Kalmeshwar Brahmani, Nagpur, Maharashtra-441501, India (rahul30.snake@gmail.com) \\ ${ }^{2}$ Kalmeshwar Brahmani, Nagpur, Maharashtra-441501, India (sd.snakefriend@gmail.com) \\ ${ }^{3}$ Tiwaskarwadi, Raipur, Hingana, Nagpur, Maharashtra-441110, India (swapnilbadhekar86@gmail.com) \\ ${ }^{4}$ Mahajanwadi near Shiwaji Park, Hanuman Temple, Hingana, Nagpur, Maharashtra-441110 (sanjaywasake01@gmail.com)
}

$\mathrm{T}^{\mathrm{s}}$

he Checkered Keelback or Asiatic Watersnake (Fowlea piscator) is among the most frequently encountered aquatic snakes and possibly the most plentiful species of snake in India (Whitaker and Captain 2005). It inhabits the whole of India to Baluchistan and the northwestern frontier provinces and extends into the Indo-Chinese region as far east as Myitkina in upper Burma (Smith 1943). It is very common in central India (Nande and Deshmukh 2007; Deshmukh et al. 2015), where it occurs in and around rivers, ponds, and paddy fields. Extremely active, these snakes are capable of jumping off the ground, and in water they swim nimbly and are capable divers (Daniel 2002). They feed on frog eggs, tadpoles, frogs, fish, and occasionally on rodents and birds (Whitaker and Captain 2005). Herein we record an unusual attempt of self-canibbalism or autophagous behavior.

We rescued a gravid adult female Checkered Keelback $(-1,120 \mathrm{~mm}$ total length) at $0845 \mathrm{~h}$ on 5 August 2019 in a seasonal pond near Buddha Vihar, Mahajanwadi, Hingana, Nagpur, Maharashtra, India $\left(21^{\circ} 08^{\prime} 78.18^{\prime \prime} \mathrm{N}, 78^{\circ} 97^{\prime} 78.18^{\prime \prime} \mathrm{E}\right)$ and placed it in a clean transparent plastic jar. The snake was

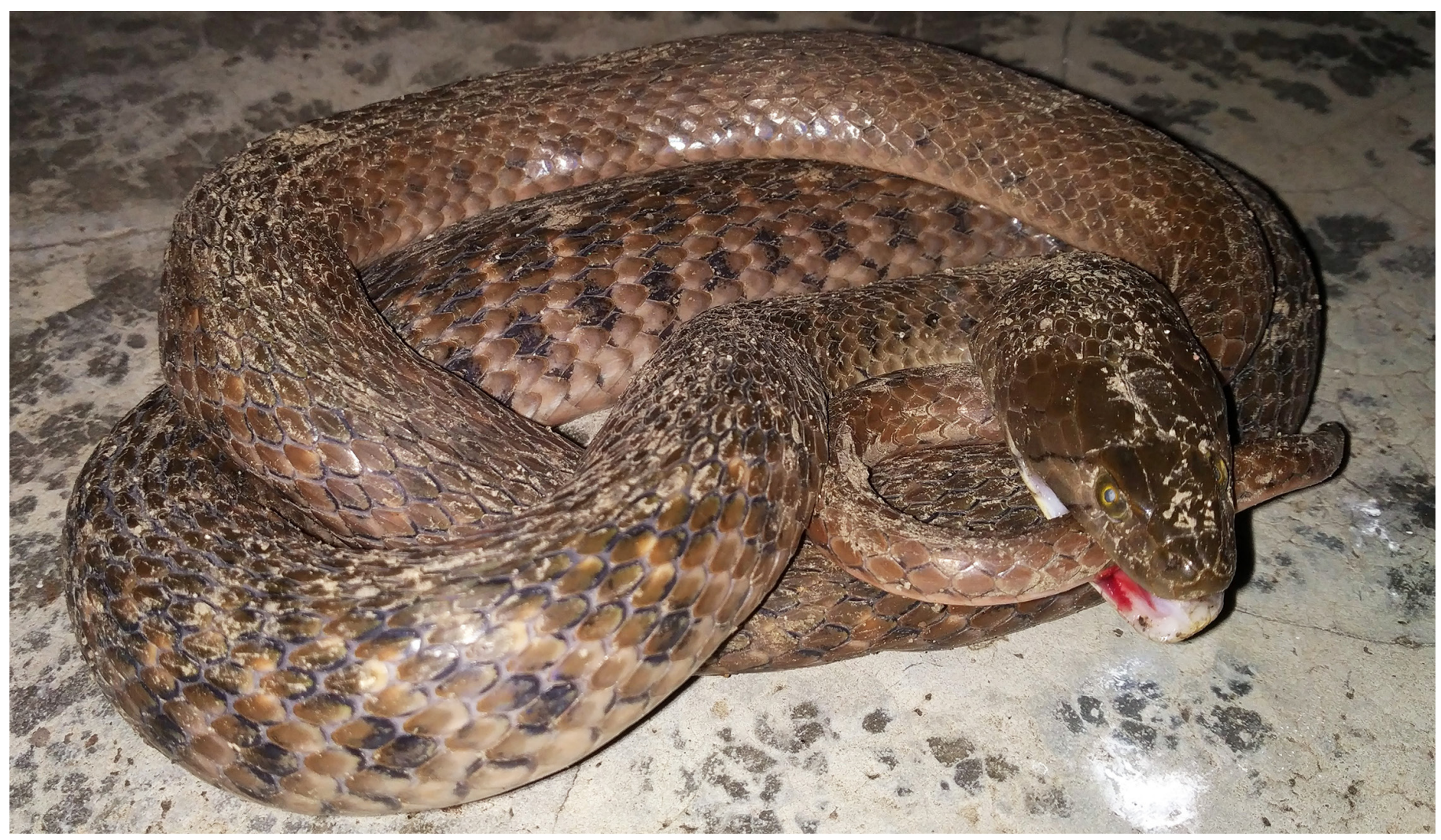

Fig. 1. An apparent attempt at autophagy by a Checkered Keelback (Fowlea piscator) in India. Photograph by Rahul V. Deshmukh. 
very aggressive when rescued and continued to strike repeatedly in the container. At $1000 \mathrm{~h}$ the next morning, Sanjay Wasake found the snake dead while biting its own tail (Fig. 1).

Autophagy has been occasionally observed in snakes but is rarely documented (Mitchell et al. 1982; Rossi and Rossi 2002; Mattison 2007). Carlino and Pauwels (2015) attributed such behavior to stress generated by captivity, which appeared to be the case in this instance as well.

\section{Acknowledgements}

We are grateful to Swapnil Bhondawe, Subham Katgube, Krutik Bhachale, Ritek Shete, and Sagar Kanfade, who have helped us in many ways.

\section{Literature Cited}

Carlino, P. and O.S.G. Pauwels. 2015. A case of self-cannibalism in a wild-caught South-Italian Alps Viper, Vipera aspis hugyi (Squamata: Viperidae). Bulletin of the Chicago Herpetological Society 50: 137.

Daniel, J.C. 2002. The Book of Indian Reptiles and Amphibians. Bombay Natural History Society, Mumbai, India.

Deshmukh, R.V., S.A. Deshmukh, and S.A. Badhekar. 2015. Rescued records of snakes from Nagpur District, Maharashtra with data on unrecorded species. Reptile Rap 17: 34-46.

Mitchell, J.C., C.A. Pague, and D.L. Early. 1982. Elaphe obsoleta (Black Rat Snake). Autophagy. Herpetological Review 13: 47.

Mattison, C. 2007. The New Encyclopedia of Snakes. Princeton University Press, Princeton, New Jersey, USA.

Nande, R. and R. Deshmukh. 2007. Snakes of Amaravati District including Melghat, Maharashtra, with important records of the Indian egg eater, montane trinket snake and Indian smooth snake. Zoos' Print Journal 22: 2920-2924.

Rossi, J. and R. Rossi. 2002. "Hoop snake" found — old wive's tale may have basis in fact: Autophagous behavior in a Southern Ring-necked Snake, Diadophis punctatus punctatus, Bulletin of the Chicago Herpetological Society 37: 85-86.

Smith, M.A. 1943. The Fauna of British India, Ceylon and Burma, Including the Whole of the Indo-Chinese Sub-region. Reptilia and Amphibia. Volume IIISerpentes. Taylor and Francis, London.

Whitaker, R. and A. Captain. 2004. Snakes of India. The Field Guide. Draco Books, Chennai, India. 